\title{
Characterization of Xylanase Produced by Aspergillus niger Fermented on Corn Cob
}

\author{
Samia A. Ahmed \\ Department of Chemistry of Natural and Microbial Products, \\ National Research Center, Cairo, Egypt.
}

\begin{abstract}
$\mathbf{T}$ HE USE of waste as raw material is important for governmen economy and natural balance. This article investigates a strain of Aspergillus niger for xylanase production in solid state fermentation (SSF) using different agricultural residues without pretreatment. The organism produced $164.4(\mu \mathrm{mol} / \mathrm{ml} / \mathrm{min})$ of xylanase in static flask on corn cob, an inexpensive lignocellulosic biomass, without enrichment of medium (only distilled water). Using surfactant solution (Tween $80,1 \%$ ) for enzyme extraction from solid substrate increased the yield by $52.5 \%$. Maximum xylanase activity was recorded at $55^{\circ} \mathrm{C}$, with high activity at wide range of temperature $\left(50-60^{\circ} \mathrm{C}\right)$. The enzyme produced on corn cob showed good thermal stability with residual activity of 62.1 and $54.3 \%$ after $2 \mathrm{hr}$ incubation at 50 and $60^{\circ} \mathrm{C}$, respectively. Addition of glycerol $(50 \%)$ improved stability against temperature by $19.9 \%$ after incubation at $60^{\circ} \mathrm{C}$ for $1 \mathrm{hr}$, and $17.8 \%$ after incubation at $60^{\circ} \mathrm{C}$ for $2 \mathrm{hr}$. The optimum $\mathrm{pH}$ for the enzyme activity was 4.5 , increasing $\mathrm{pH}$ causing decreasing in activity. Xylanase enzyme was stable at different $\mathrm{pH}$ 's after $1 \mathrm{hr}$ with remaining activity of $89.6 \%$ and $55.0 \%$, respectively at $\mathrm{pH} 4.0$ and 9.0. The enzyme possessed 70.6 and $37.6 \%$ of its activity by storage at room temperature after 10 and 30 days. In presence of metal ions such as $\mathrm{Na}^{2+}, \mathrm{Ca}^{2+}$ and protein disulphide reducing agents such as dithiothreitol (DTT), the activity of enzyme was increased by 34.9, 10.7 and $32.8 \%$, respectively. Sodium dodecyl sulphate (SDS) and $\mathrm{Cu}^{2+}$ ion strongly inhibited the enzyme by 56.8 and $23.7 \%$, respectively. Saccarification of different wastes by the enzyme was studied. The highest yield of reducing sugars $(20.3 \mathrm{mg} / 200 \mathrm{mg}$ dry weight substrate) was obtained from corn cob with maximum saccharification after $72 \mathrm{hr}(71.8 \%)$ as compared to other wastes.
\end{abstract}

Keywords: Lignocellulosic biomass, Xylanase, Stability, Saccharification.

The ability of some microorganisms to metabolize lignin and hemicelluloses make them potentially important to take advantage of agricultural residues. Agricultural and agro-industrial wastes, like sugar cane bagasse, wheat bran, rice peel, corn straw, corn cob, fruit peels etc. have increased as result of industrialization and thus becoming a problem regarding environmental pollution

For Corresponding : Telephone: 002026347972

Fax : 002023370931

E-mail: dr_sa_ahmed@yahoo.com 
(da Silva et al., 2005). Academic and industrial researchers are putting more effort to reduce the amount of such wastes by finding alternative uses in order to take advantage of the nutrients found in residues matter (Herculano et al., 2011). Hemicellulose is the second most abundant plant fraction available in nature. Agricultural residues contain up to $40 \%$ hemicelluloses formed by pentose sugars (Magge \& Kosaric, 1985). Xylanases are responsible for xylan hydrolysis, which is the main polysaccharide component of hemicelluloses in hard wood and grasses (Farinas et al., 2011). Xylan has a linear backbone of $\beta$-1,4-linked Dxylopyranose residues (Anuradha et al., 2007). There is great interest in the enzymatic hydrolysis of xylan due to possible applications in feed stock, chemical production and paper manufacturing (Coughlan \& Hazlewood, 1997). Recently, interest in xylanases has markedly increased due to the potential application in pulping and bleaching processes, animal feed, textile processes, enzymatic saccharification of lignocellulosic materials and waste treatment (Wong et al., 1988; Mechaly et al., 1997; Arabi et al., 2011 and Kaur et al., 2011). They can be used for reducing both juice viscosity and turbidity, hydrolysis of xylan into xylose to be converted biologically to single cell protein, fuels and chemicals (Lemos et al., 2000). Most of these processes are carried out at high temperatures, so that thermostable enzymes find applications (Sonnleitner \& Fiechter, 1983). Several studies have shown that the xylanases are co-induced in response to xylan or natural substrates containing hemicellulose or even by pure cellulose (Ganju et al., 1989 and Kadowaki $\&$ Souza, 1997). Many filamentous fungi secrete hydrolyzing enzymes into their culture media and are employed for the hydrolysis of lignocellulosic materials (Okafor et al., 2007). Most studies on the production of xylanases have been investigated in submerged liquid culture. There have been few reports on xylanase production in solid state fermentation (SSF) using agricultural residues without chemical pretreatment or xylan addition (Couri et al., 2000; Souza et al., 2001; Yang et al., 2001 and Kaur et al., 2011). The cost of the enzyme is one of the main factors determining the economics of the process (Xu et al., 2005). SSF an environment friendly and cost effective technology which involves the growth and metabolism of microorganisms on most solids, generally cheap agricultural residues in absence or near absence of any free flowing water, which mimics the natural habitats of microbes has proven to be an efficient fermentation system in producing certain enzymes and metabolites including xylanases (Khandeparkar \& Bhosle, 2006; Mohana et al., 2008 and Arabi et al., 2011). The aim of this work is to evaluate the potential use some agricultural residues as cost-effective substrates for xylanase production by Aspergillus niger and its properties.

\section{Materials and Methods}

\section{Microorganism}

Aspergillus niger was obtained from the Culture Collection of the National Research Centre, Dokki, Cairo, Egypt. It was maintained at $4^{\circ} \mathrm{C}$ on Potato Dextrose Agar (PDA) slants. Spores suspensions were prepared from 4-days-old

Egypt. J.Microbiol. 46 (2011) 
cultures that had been grown on PDA slopes at $37^{\circ} \mathrm{C}$. Sterile distilled water was aseptically added to each slope and a suspension of the spores was made by lightly brushing the mycelium with a sterile wire loop. The spore concentration in the suspension was determined by counting the spores in a Neubauer chamber (Hemacytometer). The inoculum volume used to inoculate the fermentation medium was calculated to obtain a final concentration of $10^{8}$ spores $/ \mathrm{ml}$.

\section{Medium and cultivation}

The medium used for xylanase production was composed $(\mathrm{g} / \mathrm{l})$ : xylan (birch wood xylan), 7; peptone, 5 ; yeast extract, $1 ; \mathrm{NaCl}, 5 ; \mathrm{K}_{2} \mathrm{HPO}_{4}, 1 ; \mathrm{MgSO}_{4} .7 \mathrm{H}_{2} \mathrm{O}$, $0.2 ; \mathrm{CaCl}_{2}, 0.1$. The initial $\mathrm{pH}$ value of the medium was adjusted to 7.0 and the medium was sterilized at $121^{\circ} \mathrm{C}$ for $20 \mathrm{~min}$. For inoculation $2.5 \mathrm{ml}$ of spore suspensions was inoculated into $50 \mathrm{ml}$ of production medium in a $250 \mathrm{ml}$ Erlenmeyer flask (final concentration $10^{8}$ spores $/ \mathrm{ml}$ ), and incubated at $37^{\circ} \mathrm{C}$, $180 \mathrm{rpm}$ for 7 days. At the end of fermentation, the mycelium was separated from the enzyme-containing broth by centrifugation at $10000 \mathrm{x} \mathrm{g}$ for $15 \mathrm{~min}$ at $4^{\circ} \mathrm{C}$ to obtain the crude enzyme.

\section{Solid state fermentation}

The agricultural residues (corn cob, saw dust, wheat bran, orange peels, rice straw and molukhiyah stem) were dried and powdered to a diameter of $1.0 \mathrm{~mm}$. The solid media were prepared by mixing $5 \mathrm{ml}$ of distilled water with $2 \mathrm{~g}$ of solid substrate and sterilized at $121^{\circ} \mathrm{C}$ for $20 \mathrm{~min}$. For inoculum preparation, $2.5 \mathrm{ml}$ of diluted spore suspension (final concentration $10^{8}$ spores/ ml) of Aspergillus niger was inoculated into solid medium in a $250 \mathrm{ml}$-Erlenmeyer flask, and incubated at $37^{\circ} \mathrm{C}$ for 7 days under shaking (180 rpm) and static conditions.

\section{Enzyme extraction and assay}

Enzyme extraction was achieved by adding $50 \mathrm{ml}$ of distilled water, acetate buffer $(0.05 \mathrm{M}$; pH 5.0) or Tween 80 solution (1\%) to each flask. The flasks were then placed on a rotary shaker $180 \mathrm{rpm}$ at $30^{\circ} \mathrm{C}$ for $30 \mathrm{~min}$. Crude extracts were centrifuged at $10000 \mathrm{x}$ g for $20 \mathrm{~min}$ and then the supernatant was used for enzyme activities assays. Xylanase activity was assayed by measuring the reducing sugar released from xylan. The reaction mixture containing $0.5 \mathrm{ml}$ of birch wood xylan (Sigma) solution $1 \%(\mathrm{w} / \mathrm{v})$, in acetate buffer $(0.05 \mathrm{M} ; \mathrm{pH} 4.5)$ and were incubated at $45^{\circ} \mathrm{C}$ for $30 \mathrm{~min}$. The reducing sugars released were determined by Somogyi (1952). The unit of xylanase activity (U) was defined as the number of $\mu$ mol of reducing sugars formed per ml per min under assay conditions.

\section{Enzyme properties}

\section{Effect of temperature}

The enzymatic reactions were carried out at different temperatures ranged from 30 to $75^{\circ} \mathrm{C}$ and the activity measurements were determined as described above. 
Thermal stability

The thermostability of enzyme was determined by measuring the residual activity after incubating the enzyme at various temperatures ranging from 40 to $70^{\circ} \mathrm{C}$ for $30,60,90$, and $120 \mathrm{~min}$.

\section{Stability at $50 \%$ glycerol}

Glycerol was added to the enzyme solution at the beginning of the preincubation, at a final concentration of 50\%. Measurements were carried out after pre-incubation at different temperatures $\left(40,50,60\right.$, and $\left.70^{\circ} \mathrm{C}\right)$ for interval times $(30,60,90$ and $120 \mathrm{~min})$, and the residual activity was determined at $55^{\circ} \mathrm{C}$.

\section{Effect of $p H$ and $p H$ stability}

Optimum $\mathrm{pH}$ was determined by measuring the activity at optimum temperature over the $\mathrm{pH}$ range of 3.5-10.0 using following buffers $(0.05 \mathrm{M})$ : Acetate buffer (3.5 - 4.5), Citrate buffer (5.0 - 6.0), Phosphate buffer (7.0 - 8.0), and Glycine-NaOH buffer $(9.0-10.0)$. Xylanase stability was measured over $\mathrm{pH}$ range of 4.0-10.0 by incubating $0.5 \mathrm{ml}$ enzyme and $1.5 \mathrm{ml}$ of different buffers (as explained above) for $60 \mathrm{~min}$ at $30^{\circ} \mathrm{C}$. After incubation, residual activity was determined under optimal assay conditions.

\section{Storage stability}

Residual activity was determined after incubating the enzyme at room temperature $\left(25^{\circ} \mathrm{C}\right)$ for several periods $(1,5,10,15,20,25$ and 30 days $)$.

Effect of chemical reagents on xylanase activity

The enzyme was incubated at $30^{\circ} \mathrm{C}$ for $1 \mathrm{hr}$ with $10 \mathrm{mM}$ solution of different chemical reagents like $\mathrm{CaCl}_{2}, \mathrm{KCl}, \mathrm{NaCl}, \mathrm{BaCl}_{2}, \mathrm{CuSO}_{4} .5 \mathrm{H}_{2} \mathrm{O}, \mathrm{MgSO}_{4} .7 \mathrm{H}_{2} \mathrm{O}$, dithiothreitol (DTT), and sodium dodecyl sulphate (SDS). Residual activity was estimated following the procedure described above.

\section{Saccharification study}

Natural untreated lignocellulosic substrate was saccarified using xylanase enzyme. The reaction mixture contained $0.2 \mathrm{~g}$ of substrate, $8.0 \mathrm{ml}$ acetate buffer $(0.05 \mathrm{M} ; \mathrm{pH} 4.5)$ and $2.0 \mathrm{ml}$ enzyme solution (100 U). After the incubation periods $(6,24,48$ and $72 \mathrm{hr})$ at $50^{\circ} \mathrm{C}$, the reaction mixture was filtered to remove unreacted substances. The resulting filtrates were assayed for total reducing sugar at regular time intervals.

Saccarification $\%=[$ Reducing sugar $(\mathrm{mg}) /$ Total carbohydrates $(\mathrm{mg})] \mathrm{X} 0.9 \mathrm{X} 100$

\section{Determination of total carbohydrates}

Total carbohydrates were determined as xylose according to the method of Dubois et al. (1956). 
Statistical analysis

Data were analyzed through least significant differences using the statistic analysis system SPSS software (Version 16). Statistical analysis for xylanase production by SSF and its properties are presented in Table 3.

\section{Results and Discussion}

\section{Enzyme production}

Xylanase from microbes are inducible enzymes which determine the great significance of nutrient composition. The high xylan content in some of the wastes like corn cob makes them an accessible and cheap source of inducers (Mohana et al., 2008). Crude enzyme in this study was produced using submerged fermentation (SmF) and solid state fermentation (SSF). Preliminary observation (Fig.1) have demonstrated that Aspergillus niger produces considerable levels of xylanase when grown in corn cob by SSF under static condition (164.4 U) but lower levels by SmF under shaking condition (27.9 U) with significant variation $(\mathrm{p}<0.05)$. The enzyme production under static condition was 68-fold higher in SSF than that in $\operatorname{SmF}(p<0.05)$. This may be explained because the growth conditions in SSF are very similar to natural habitat, which favors the spreading of mycelium and consequently, results in a larger production of enzymes and better growth ( Leite et al., 2007 and Farinas et al., 2011). Many studies about the application of SSF are focused in adding value to agro industry residues, which have been extensively used as physical support or source of nutrients (Soccol \& Van denberghe, 2003; Agnihotri et al., 2010 and Bokhari et al., 2010). Corn cob, the central wooden core of maize has recognized as a useful and cost-effective medium ingredient, because it is largely produced as a by-product during the corn processing (da Silva et al., 2005 and Xiros et al., 2008). In this work, it is interesting that corn cob residue without any pretreatment was used as excellent carbon source for enzyme production by fungi and the growth medium was not supplied with any nutrients or saline solution, only distilled water was used to humidify the solid substrates.

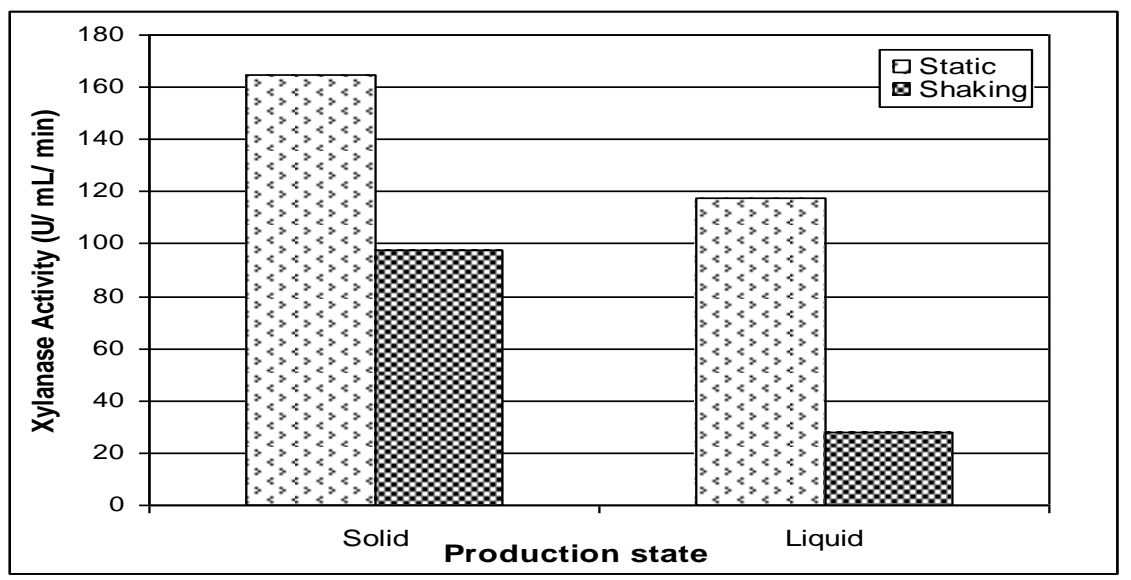

Fig. 1. Production of xylanase enzyme using different conditions. 


\section{Enzyme extraction}

Some enzymes produced under SSF have been recovered from the solid phase by treatment with distilled water (Xiros et al., 2008), surfactant Tween 80 (Silveira et al., 1997), or buffer solution (Couri et al., 2000). In this study, $50 \mathrm{ml}$ of extraction systems employed, water, acetate buffer (0.05 M; pH 5.0), and Tween $80(1 \%)$, were found to be efficient in recovering xylanase. The time of extraction was 30 min under shaking conditions $(180 \mathrm{rpm})$ and temperature $30^{\circ} \mathrm{C}$. The highest enzyme extraction $(250.7 \mathrm{U})$ was obtained by Tween 80 . This result is in agreement with Rezende et al. (2002), who found that Tween 80 $(0.1 \%)$ was the most suitable for extraction of Trichoderma harzianum xylanase after $15 \mathrm{~min}$. On the other hand, the lowest extraction of Aspergillus niger xylanase $(96.6 \mathrm{U})$ was obtained by acetate buffer (data not shown).

\section{Enzyme properties}

Effect of temperature

Effect of the temperature in the activity of xylanase enzyme (Fig. 2), shows that the optimum temperature was $55^{\circ} \mathrm{C}$ yielding $269.7 \mathrm{U}$ and statistically highly significant $(\mathrm{p}=0.00)$. This result is similar to that reported by Durand et al. (1984) and Agnihotri et al. (2010). On the other side the result is slightly higher than that found by Leite et al. (2007), who found that optimum temperature for Aureobasidium pullans xylanase was $50^{\circ} \mathrm{C}$.

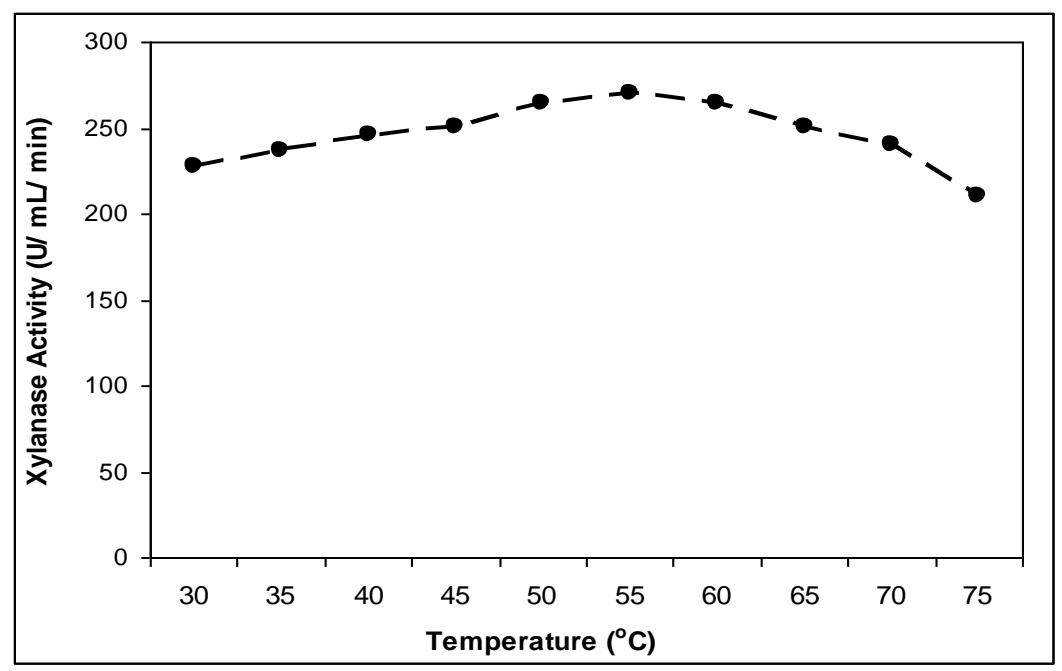

Fig. 2. Effect of temperature on the activity of xylanase enzyme.

\section{Thermal stability}

Enzyme stability to heat inactivation is important property due to its potential applications in several industrial processes (Table 1). The enzyme retained $64.3 \%$ and $60.2 \%$ of its activity by pre-incubating at $50^{\circ} \mathrm{C}$ and $60^{\circ} \mathrm{C}$, respectively, for $1 \mathrm{hr}$ with high significant $(\mathrm{p}=0.00)$. At $70^{\circ} \mathrm{C}$ the enzyme 
retained $50.0 \%$ of its activity after $2 \mathrm{hr}$. Mohana et al. (2008), pointed to the loss in activity of Burkholderia sp. DMAX xylanase $(50.0 \%)$ after heating at $60^{\circ} \mathrm{C}$ for $1 \mathrm{hr}$. The results in this study is superior to that reported by $\mathrm{Li}$ et al. (2007) on xylanase from Penicilliu oxalicum ZH-30, which was completely inhibited (only retained $0.9 \%$ ) within 15 min pre-incubating at $70^{\circ} \mathrm{C}$. Kaur et al. (2011) reported that crude xylanase extracted from Coprinopsis cinerea HK-1 was retained $50 \%$ of its activity when incubated at $55^{\circ} \mathrm{C}$ for $15 \mathrm{~min}$. The use of thermostable enzymes to carry out hydrolysis at higher temperatures is advantageous because it increases the reaction speed and it prevents microbial contamination thus contributing to increase the economical and biotechnical viability of the process (Gomes et. al., 1994 and da Silva et al., 2005).

\section{Stabilization by glycerol $50 \%$}

In order to avoid thermal inactivation, the eventual protective effect of glycerol (at $50 \%$ ) in aqueous medium was investigated and the results are exhibited in Table 1, which xylanase stability could be improved by glycerol, and there were highly significant increases $(\mathrm{p}=0.00)$ from 64.3 and $60.2 \%$, to 78.3 and $72.2 \%$, respectively, after $1 \mathrm{hr}$ at 50 and $60^{\circ} \mathrm{C}$. The phenomenon of protein stabilization by polyols may be explained by changes in the microenvironment of the enzyme, which result in a more rigid conformation of enzyme structure. Probably, the benefit of polyols is related to the effect they promote by increasing the degree of organization of water molecules, which in turn, intensify the hydrophobic interactions among non polar groups. Hydrophobic interactions appear to be the single most important factor to stabilize protein structure, therefore making the protein more resistant to unfolding (Klibanov, 1983 and Lemos et al., 2000). Angelo et al. (1997), found that the stability of xylanase from Aspergillus sp. was markedly improved by the addition of $50 \%$ glycerol. Also, Duarte et al. (2000) reported that stability of Bacillus pumilus xylanase could be enhanced by glycerol and the increase was from $15 \%$ to $36 \%$, after $2 \mathrm{hr}$ at $50^{\circ} \mathrm{C}$.

TABLE 1. Thermal stability of xylanase enzyme.

\begin{tabular}{|c|c|c|c|c|c|c|c|c|}
\hline \multirow{7}{*}{\begin{tabular}{c} 
Time of $\begin{array}{c}\text { Reating } \\
\text { (min) }\end{array}$ \\
\cline { 2 - 9 } $\begin{array}{c}\text { Temperature } \\
\left({ }^{\circ} \mathbf{C}\right)\end{array}$
\end{tabular}} & \multicolumn{9}{|c|}{ without glycerol } & \multicolumn{5}{c|}{ with glycerol } \\
\hline & $\mathbf{3 0}$ & $\mathbf{6 0}$ & $\mathbf{9 0}$ & $\mathbf{1 2 0}$ & $\mathbf{3 0}$ & $\mathbf{6 0}$ & $\mathbf{9 0}$ & $\mathbf{1 2 0}$ \\
\hline 40 & 96.20 & 94.0 & 91.3 & 89.8 & 100 & 100 & 100 & 100 \\
\hline 50 & 66.30 & 64.25 & 63.81 & 62.09 & 80.01 & 78.32 & 74.48 & 70.02 \\
\hline 60 & 61.67 & 60.16 & 56.88 & 54.31 & 74.40 & 72.18 & 67.18 & 63.99 \\
\hline 70 & 58.90 & 55.78 & 52.96 & 50.00 & 68.40 & 66.10 & 63.13 & 61.35 \\
\hline
\end{tabular}


Effect of $p H$

Enzyme activity is markedly affected by $\mathrm{pH}$. This is because substrate binding and catalysis is often dependent on charge distribution on both, substrate and particularly enzyme molecules (Mohana et al., 2008). The optimum $\mathrm{pH}$ for xylanase activity was detected to be 4.5 yielding $(269.7 \mathrm{U})$ with high significant variation $(\mathrm{p}=0.00)$. As results in Fig. 3 , the activity decreased by increasing of $\mathrm{pH}$. Xylanase produced by Aureobasidium pulluans had a maximum activity at pH 5.0 (Leite et al., 2007).

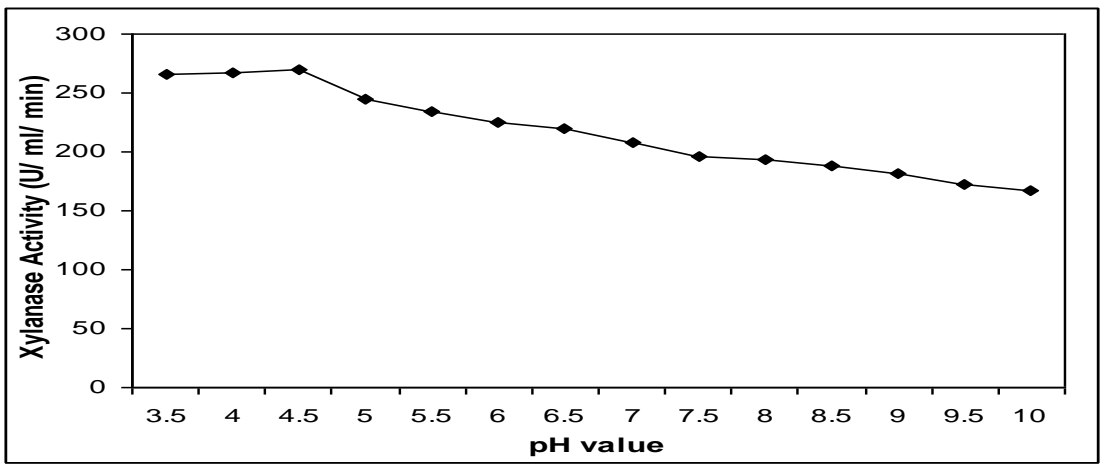

Fig. 3. Effect of pH on the activity of xylanase enzyme.

pH stability

The results obtained after incubation of the enzyme at different $\mathrm{pH}$ values for $1 \mathrm{hr}$ pointed to high significant variation $(\mathrm{p}=0.00)$ and presented in Fig. 4. Xylanase retained $63.1 \%$ of its activity after incubation at $\mathrm{pH} 7.0$ However, at pH 10.0 the activity decreased rapidly and the enzyme retained $46.6 \%$ of its activity. This result is in contrast with that obtained by Leite et al. (2007), who found that Aureobasidium pulluans xylanase maintained $53 \%$ of its original activity after 1 day at $\mathrm{pH} 11.0$.

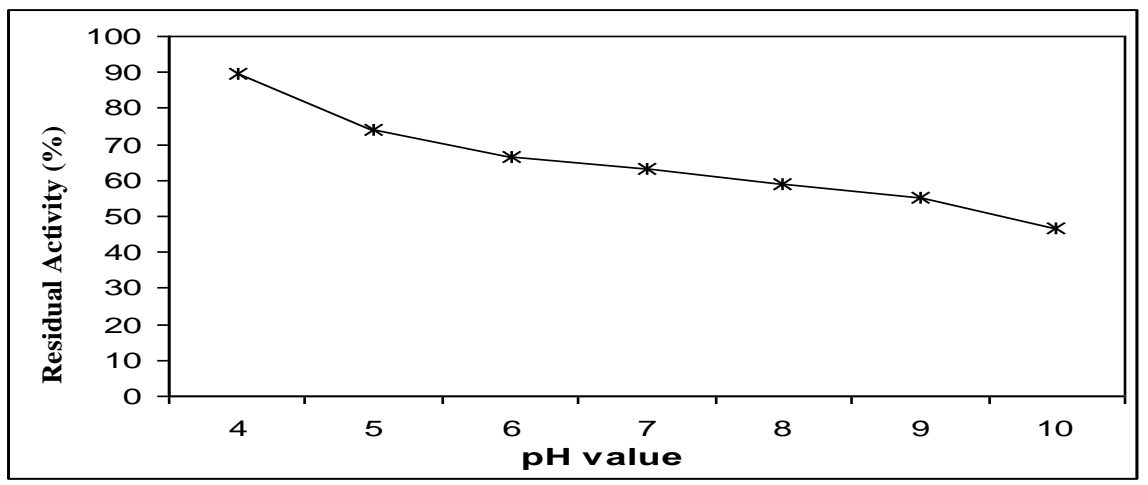

Fig. 4. pH stability of xylanase enzyme.

Egypt. J.Microbiol. 46 (2011) 


\section{Storage at room temperature}

Experiments were also carried out to estimate the enzyme stability concerning its storage at room temperature $\left(\sim 25^{\circ} \mathrm{C}\right)$. The retained activity obtained after 5 days was $89.3 \%$. The results in Fig. 5 pointed to high significant variation $(\mathrm{p}=0.00)$ and showed that xylanase enzyme seems to be resistant to storage for 15 days with residual activity $62.6 \%$ and these results are interesting for application due to the ability of enzyme storage at room temperature and decrease the storage cost.

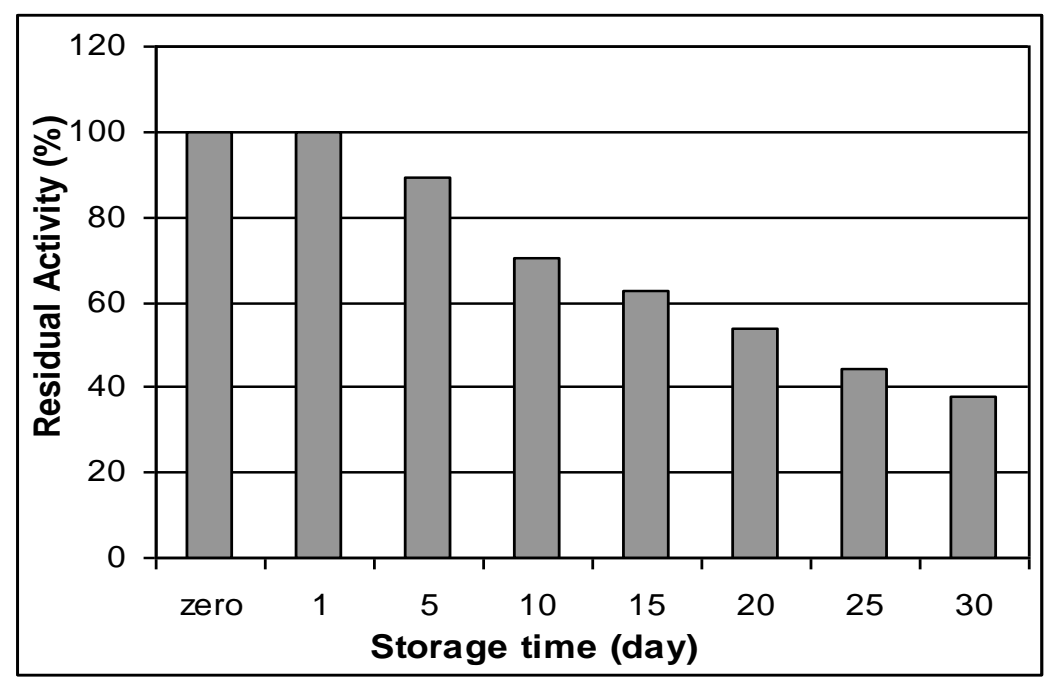

Fig. 5. Stabilty of xylanase enzyme at room temperature.

\section{Effect of chemical reagents}

The influence of different chemical reagents on xylanase activity is given in Fig. 6. Xylanase activity was stimulated with significant variation $(\mathrm{p}<0.05)$ in the presence of $\mathrm{CaCl}_{2}, \mathrm{KCl}, \mathrm{BaCl}_{2}$ and $\mathrm{MgSO}_{4} \cdot 7 \mathrm{H}_{2} \mathrm{O} . \mathrm{NaCl}$ caused highest increase in enzyme activity (134.9\%), perhaps due to alteration of enzyme conformation (Anuradha et al., 2007). Metal ions can be involved in enzyme catalysis in a variety of ways, they may : (1) Accept or donate electrons, (2) Themselves act as electrophiles, (3) Mask nucleophiles to prevent unwanted side reactions, (4) Bring together enzyme and substrate by coordinate bonds, (5) Hold the reacting groups in the required 3D orientation, and (6) Simply stabilize a catalytically active conformation of the enzyme (Palmer, 2001 and Mohana et al., 2008). The protein disulphide reducing reagent DTT caused high stimulation of enzyme (132.8\% relative activity), confirming the presence of a reduced thiol group of cysteine as a part of the catalytic site in the enzyme structure, such thiol compounds prevent oxidation of this group (Anuradha et al., 2007). 


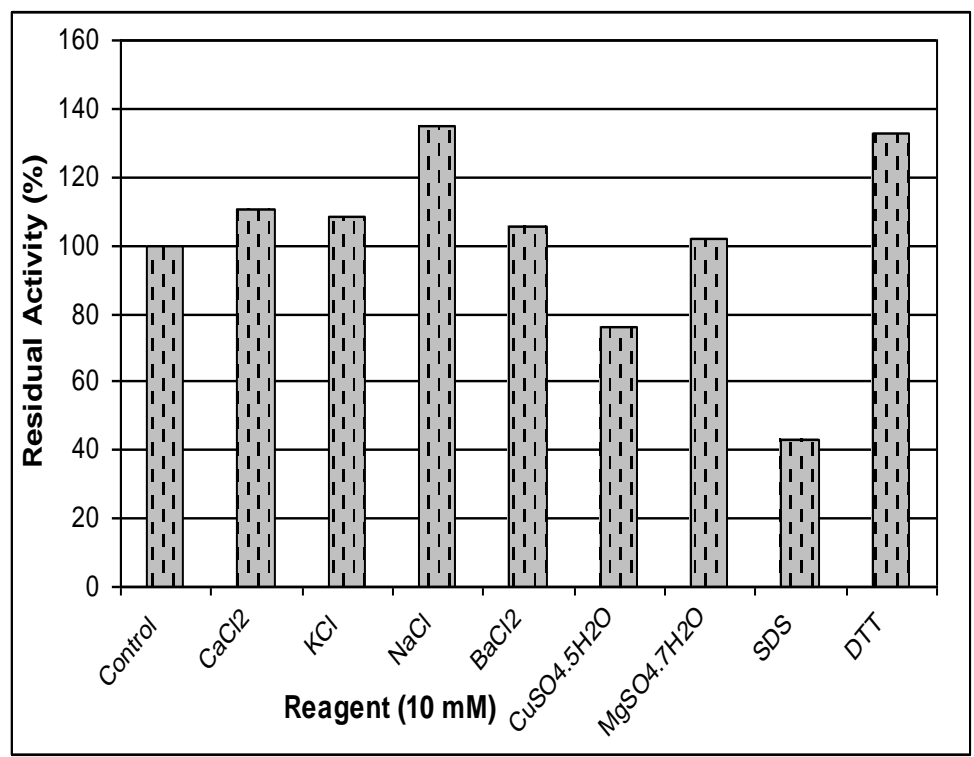

Fig. 6. Effect of some chemical reagent on xylanase activity.

\section{Saccharification study}

Results for saccarification of different agricultural residues using xylanase enzyme are depicted in Table 2. Corn cob was found to be more susceptible to hydrolysis than other substrates and statistically significant $(\mathrm{p}<0.05)$ after $72 \mathrm{hr}$ rendering $(20.3 \mathrm{mg} / 200 \mathrm{mg}$ dry weight of corn cob) fermentable sugars corresponding to $71.8 \%$ of the saccharificable material. Prolonged subjection of the wastes to enzyme treatment for more than $72 \mathrm{hr}$, showed no significant enhancement in the liberation of reducing sugars (data not shown). Also, xylanase enzyme could hydrolysis wheat bran with high value of saccarification (70.6 \%) after the same incubation period. Mohana et al. (2008) reported reducing sugar liberation by saccharification of lingocellulosic waste using crude xylanase from Burkholderia sp. DMAX. Also, Heck et al. (2006), pointed to the saccharification of agroindustrial waste by xylanase from $B$. circulans.

\section{Statistical analysis}

Statistical analysis results for xylanase production by SSF and its properties are presented in Table 3A, B . 
TABLE 2. Saccharification study of some agricultural wastes.

\begin{tabular}{|c|c|c|c|c|}
\hline $\begin{array}{c}\text { Agriculture } \\
\text { wastes }\end{array}$ & $\begin{array}{c}\text { Total } \\
\text { carbohydrate } \\
(\mathbf{m g})\end{array}$ & $\begin{array}{c}\text { Incubation } \\
\text { period } \\
\text { (hr) }\end{array}$ & $\begin{array}{l}\text { Reducing } \\
\text { sugar } \\
\text { (mg) }\end{array}$ & $\begin{array}{c}\text { Saccharification } \\
(\%)\end{array}$ \\
\hline \multirow{4}{*}{ Saw dust } & \multirow{4}{*}{14.99} & 6 & 3.35 & 20.11 \\
\hline & & 24 & 5.04 & 30.26 \\
\hline & & 48 & 6.18 & 37.10 \\
\hline & & 72 & 6.75 & 40.53 \\
\hline \multirow{4}{*}{ Wheat bran } & \multirow{4}{*}{11.99} & 6 & 5.41 & 40.61 \\
\hline & & 24 & 8.59 & 64.48 \\
\hline & & 48 & 9.16 & 68.77 \\
\hline & & 72 & 9.40 & 70.56 \\
\hline \multirow{4}{*}{$\begin{array}{l}\text { Molukiyah } \\
\text { stem }\end{array}$} & \multirow{4}{*}{25.54} & 6 & 7.12 & 25.09 \\
\hline & & 24 & 8.46 & 29.81 \\
\hline & & 48 & 10.94 & 38.55 \\
\hline & & 72 & 12.31 & 43.38 \\
\hline \multirow{4}{*}{ Rice straw } & \multirow{4}{*}{28.22} & 6 & 3.71 & 11.83 \\
\hline & & 24 & 8.99 & 28.67 \\
\hline & & 48 & 15.03 & 47.93 \\
\hline & & 72 & 15.26 & 48.67 \\
\hline \multirow{4}{*}{ Corn cob } & \multirow{4}{*}{25.50} & 6 & 10.07 & 35.54 \\
\hline & & 24 & 15.19 & 53.61 \\
\hline & & 48 & 19.39 & 68.44 \\
\hline & & 72 & 20.34 & 71.79 \\
\hline
\end{tabular}

TABLE 3A. Statistical analysis for xylanase production by SSF and its thermal stability.

\begin{tabular}{|l|c|c|}
\hline \multicolumn{1}{|c|}{ Factor } & t & P \\
\hline Static/ Shaking & 2.751 & 0.016 \\
\hline Solid/ Liquid & 4.938 & 0.00 \\
\hline $\begin{array}{l}\text { Static/ Shaking } \\
\text { (in solid) }\end{array}$ & $1.969 \mathrm{E} 16$ & 0.00 \\
\hline $\begin{array}{l}\text { Static/ Shaking } \\
\text { (in liquid) }\end{array}$ & $2.858 \mathrm{E} 16$ & 0.00 \\
\hline $\begin{array}{l}\text { Thermal stability } \\
\text { (with/ without glycerol) }\end{array}$ & -1.885 & 0.05 \\
\hline
\end{tabular}

High significant $(\mathrm{P}<0.01)$; Significant $(\mathrm{P}<0.05)$; Not significant $(\mathrm{P}>0.05)$.

TABLE 3B. Statistical analysis for xylanase properties.

\begin{tabular}{|l|c|c|}
\hline \multicolumn{1}{|c|}{ Factor } & F & P \\
\hline Temperature & $1.691 \mathrm{E} 3$ & 0.00 \\
\hline $\mathrm{pH}$ & $1.384 \mathrm{E} 4$ & 0.00 \\
\hline $\mathrm{pH}$ stability & 546.554 & 0.00 \\
\hline Stability at room temperature & $1.867 \mathrm{E} 3$ & 0.00 \\
\hline Metal ions & $2.818 \mathrm{E} 3$ & 0.00 \\
\hline Saccarification & 3.753 & 0.032 \\
\hline Reducing sugar & 2.607 & .0 .87 \\
\hline
\end{tabular}

High significant $(\mathrm{P}<0.01)$; Significant $(\mathrm{P}<0.05)$; Not significant $(\mathrm{P}>0.05)$. 


\section{Conclusion}

It was possible to obtain xylanase enzyme from Aspergillus niger using corn cob as cheap agricultural residue by SSF system. It is interesting to use corn cob without either pretreatment, or supplements, only distilled water was used to humidify the solid substrate. The results show good stability of the enzyme to heat inactivation and $\mathrm{pH}$, which pointed to its application in industrial process. Glycerol enhanced thermal stability of xylanase enzyme by $21.90 \%$ when incubated at $50^{\circ} \mathrm{C}$ for $1 \mathrm{hr}$. It was also possible to storage the enzyme at room temperature $\left(\sim 25^{\circ} \mathrm{C}\right)$ for a long time $(10,20$ and 30 days $)$ with high residual activity $(70.62,53.6$ and $37.59 \%$, respectively). Xylanase enzyme was able to convert agricultural wastes to fermentable sugars with higher saccarification percentage compared to other studies $(71.79 \%)$.

\section{References}

Agnihotri, S., Dutt, D., Tyagi, C.H., Kumar, A. and Upadhyay, J.S. (2010) Production and biochemical characterization of a novel cellulose-poor alkali-thermo-tolerant xylanase from Coprinellus disseminatus SW-1NTCC1165. World J. Microbiol. Biotechnol. 26, 1349-1359.

Angelo, R., Aguirre, C., Curotto, E., Esposito, E., Fontana, J.D., Baron, M., Milagres, A.M.F. and Durán, N. (1997) Stability and chemical modification of xylanase from Aspergillus sp. (2MI strain). Biotechnol. Appl. Biochem. 25, 19-27.

Anuradha, P., Vijayalakshmi, K., Prasanna, N.D. and Sridevi, K. (2007) Production and properties of alkaline xylanases from Bacillus sp. isolated from sugar cane fields. Curr. Sci. 92 (9), 1283-1286.

Arabi, M.I.E., Jawhar, M. and Bakri, Y. (2011) Effect of additional carbon source and moisture level on xylanase production by Cochliobolus sativus in solid fermentation. Microbiol. 80 (2), 150-153.

Bokhari, S.A.I., Rajoka, M.I., Javaid, A., Shafiq-ur-Rehman, Ishtiaq-ur-Rehman and Latif, F. (2010) Novel thermodynamics of xylanase formation by a 2-deoxy-Dglucose resistant mutant of Thermomyces lanuginosus and its xylanase potential for biobleachability. Bioresoure. Tecnol. 101, 2800-2808.

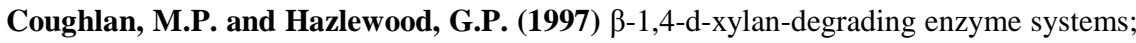
biochemistry, molecular biology and applications. Biotechnol. Appl. Biochem. 17, 259-289.

Couri, S., Terzi, S.C., Pinto, G.A., Freitas, S.P. and Costa, A.C.A. (2000) Hydrolytic enzyme production in solid-state fermentation by Aspergillus niger 3T5B8. Proc. Biochem. 36, 255-261.

da Silva, R., Lago, E.S., Merheb, C.W., Macchione, M.M., Park, Y.K. and Gomes, E. (2005) Production of xylanase and CMCase on solid state fermentation in different residues by Thermoascus aurantiacus MIEHE. Brazil. J. Microbiol. 36, 235-241.

Egypt. J.Microbiol. 46 (2011) 
Duarte, M.C.T., Pellergrino, A.C.A., Portugal, E.P., Ponezi, A.N. and Franco, T.T. (2000) Characterization of alkaline xylanases from Bacillus pumilu. Brazil. J. Microb. 31, 90-94.

Dubois, M., Gilles, K.A., Hamiltone, J.K., Robers, R.A. and Smith, F. (1956) Calorimetric methods of determination of sugars and related substances. Anal. Chem. 28, 350 .

Durand, H., Soucaille, P. and Tiraby, G. (1984) Comparative study of cellulases and hemicellulases from four fungi: mesophiles Trichoderma ressei and Penicillium sp. and themophiles Thielavia terrestris and Sporotrichum cellulophilum. Enzyme Microb. Technol. 6, 175-180.

Farinas, C.S., Scarpelini, L.M., Miranda, E.A. and Bertucci Neto, V. (2011) Evaluation of operational parameters on the precipitation of endoglucanase and xylanase production by solid state fermentation of Aspergillus niger. Brazi. J. Chem. Engin. $28(1), 17-26$.

Ganju, R.K.,Vithayathi, P.J. and Murthy, S.K. (1989) Purification and characterization of two xylanase from Chaetomium thermophile var coprphile. Can. J. Microb. 35, 836-842.

Gomes, D. J., Gomes, J. and Steiner, W. (1994) Production of highly thermostable xylanase by a wild strain of thermophilic fungus Thermoascus aurantiacus and partial characterization of the enzyme. J. Biotechnol. 37, 11-22.

Heck, J.X., Soares, L.H.B., Hertz, P.F. and Ayub, M.A.Z. (2006) Purification and properties of xylanase produced by Bacillus circulans BL53 on solid state cultivation. Biochem. Eng. J. 32, 179-184.

Herculano, P.N., Lima, D.M.M., Fernandes, M.J.S., Neves, R.P., Souza-Motta, C.M. and Porto, A.L.F. (2011) Isolation of cellulotic fungi from waste of castor (Ricinus communis L.). Curr. Microbiol. 62, 1416-1422.

Kadowaki, M.K. and Souza, C.G.M. (1997) Xylanase production by Aspergillus tamari. Appl. Biochem. Biotecnol. 66, 97-106.

Kaur, H., Dutt, D. and Tyagi, C.H. (2011) Production of novel alkali-Tolerant cellulose-poor xylanases from Coprinopsis cinera HK-1 NFCCI-2032. BioResou. 6 (2), 1376-1391.

Khandeparkar, R.D.S. and Bhosle, N.B. (2006) Isolation, purification and characterization of the xylanase produced by Arthrobacter sp. MTCC5214 when grown in solid state fermentation. Enzyme Micro. Technol. 39, 732-742.

Klibanov, A.M. (1983) Stabilization of enzymes against thermal inactivation. Adv. Appl. Microbiol. 29, 1-28.

Leite, R.S.R., Bocchini, D.A., Martins, E.Da S., Silva, D., Gomes, E. and Da Silva, R. (2007) Production of cellulolytic and hemicellulolytic enzymes from Aureobasidium pulluans on solid state fermentation. Appl. Biochem. Biotech. 136-140, 281-288. 
Lemos, J.L.S., Bon, E.P.S., Santana, M.de F.E. and Junior, N.P. (2000) Thermal stability of xylanases produced by Aspergillus awamori. Brazil. J. Microb. 31, 206211.

Li, Y., Liu, Z., Zhao, H., Xu, Y. and Cui, F. (2007) Statistical optimization of xylanase production from new isolated Penicillium oxalicum ZH-30 in submerged fermentation. Biochem. Engi. J. 34, 82-86.

Magge, R. J. and Kosaric, M. (1985) Bioconversion of hemicellulose. Adv. Biochem. Eng. Biotech. 32, 61-93.

Mechaly, A., Belakhov, V., Shoham, Y. and Bassov, T. (1997) An efficient chemicalenzymatic synthesis of 4-nitrophenyl b-xylobiosede: A chromogenic substrate for xylanases. Carboh. Res. 304, 111-115.

Mohana, S., Shah, A., Jyoti, D. and Madamwar, D. (2008) Xylanase production by Burkholderia sp. DMAX strain under solid state fermentation using distillery spent wash. Bioresour. Techn. 99, 7553-7564.

Okafor, U.A., Emezue, T.N., Okochi, V.I., Onyegeme-Okerenta, B.M. and NwodoChinedu, S. (2007) Xylanase production by Penicillium chrysogenum (PCL501) fermented on celluosic wastes, Afric. J.Biochem. Res. 1 (4), 48-53.

Palmer, T. (2001) "Enzymes: Biochemistry. Biotechnology and Chemical Chemistry". Horwood Publication, Chichester, UK. pp.191-222.

Rezende, M.I., Barbosa, A.deM., Vasconcelos, A.F.D. and Endo, A.S. (2002) Xylanase production by Trichoderma harzianum RIFAI by solid state fermentation on sugar cane bagasse. Brazil. J. Microb. 33, 67-72.

Silveira, F.Q.P., Melo, I.S. and Filho, E.X.F. (1997) Carbohydrate-hydrolysing enzyme activity production by solid-state cultures of Trichoderma harzianum strains. Rev. Microbiol. 28, 152-156.

Soccol, C.R. and Van denberghe, L.P.S. (2003) Overview of applied solid state fermentation in Brazil. Biochem. Eng. J. 13, 205-218.

Somogyi, N. (1952) Notes on sugar determination. J. Biol. Chem. 195, 19-23.

Sonnleitner, B. and Fiechter, A. (1983) Advantages of using thermophiles in biotechnological processes: Expectations and reality. Trends Biotechnol. 1, 74-80.

Souza, D.F., Souza, C.G.M. and Peralta, R.M. (2001) Effect of easily metabolizable sugars in the production of xylanase by Aspergillus tamarii in solid-state fermentation. Proc. Biochem. 36, 835-83.

Wong, K.K.Y., Tan, L.U. and Saddler, J.N. (1988) Multipilicity of b-1,4-xylanases in microorganisms: Functions and applications. Microbiol. Ver. 52, 305-317.

Xiros, C., Topakas, E., Katapodis, P. and Christakopoulos, P. (2008) Evaluation of Fusarium oxysporum as an enzyme factory for the hydrolysis of brewer's spent grain

Egypt. J.Microbiol. 46 (2011) 
with improved biodegradability for ethanol production. Indus. Crops and Prod. 28, 213-224.

Xu, Z.H., Bail, Y.L., Xu, X., Shi, J.S. and Tao, W.I. (2005) Production of alkali-tolerant cellulose-free xylanase by Pseudomonase sp. UN024 with wheat bran as the main substrate., World J. Microbiol. Biotechnol. 21, 575-581.

Yang, X., Cheng, H., Gao, H. and Li, Z. (2001) Bioconversion of corn straw by coupling ensiling and solid-state fermentation. Biores. Technol. 78, 277-280.

(Received 29/3/2011;

accepted 19/6/2011) 


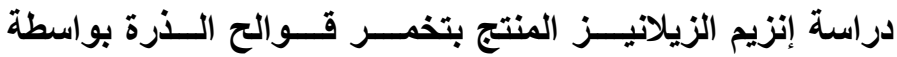 \\ Aspergillus niger
}

\author{
سامية عبد العزيز أحمد \\ قسم كيمياء المنتجات الطبيعية والميكروبيةـ المركز القومي للبحوث - ـ القاهرة -
}

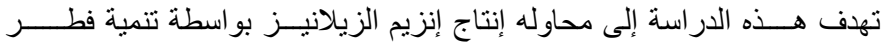
Aspergillus niger

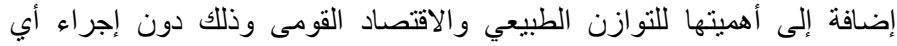

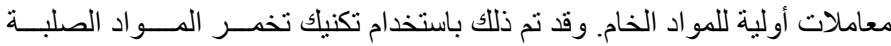
( أظهر البحث القدرة العالية للفطر المستخدم (Solid State Fermentation)

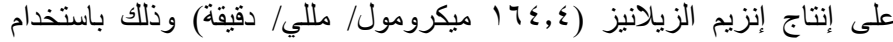

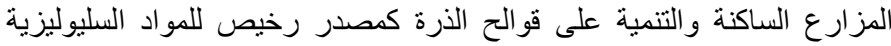

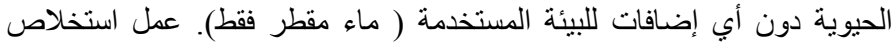

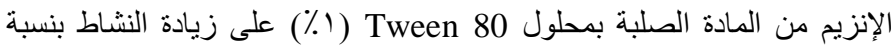

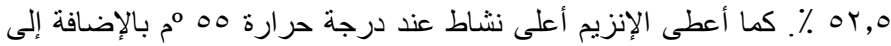

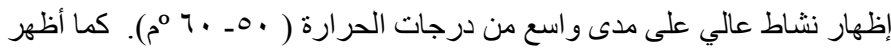

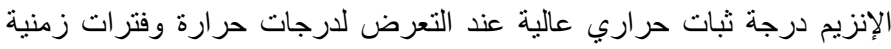

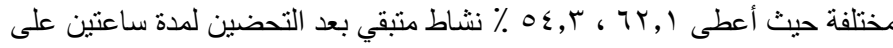

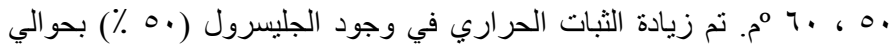

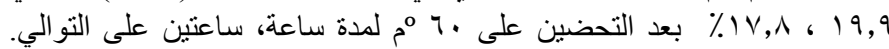

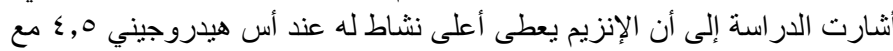

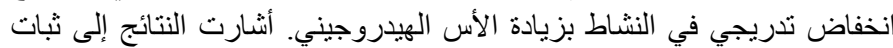

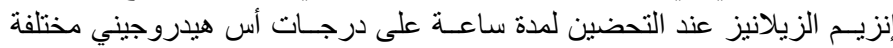

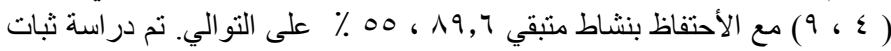

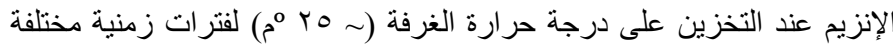

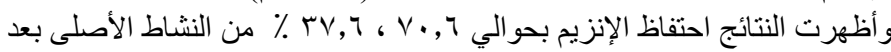

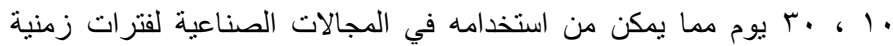

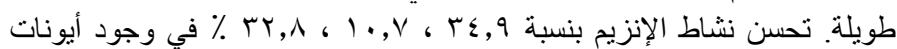

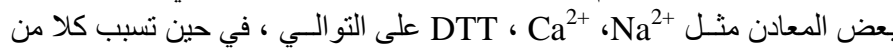

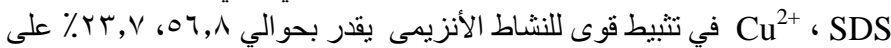

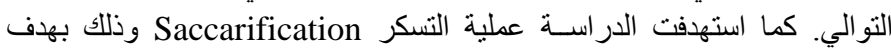

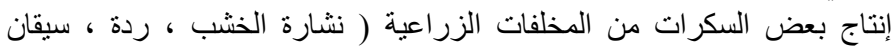

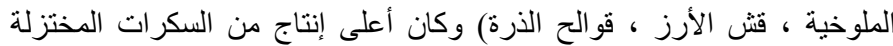

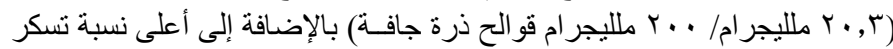

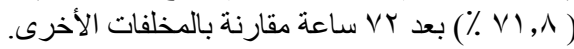

